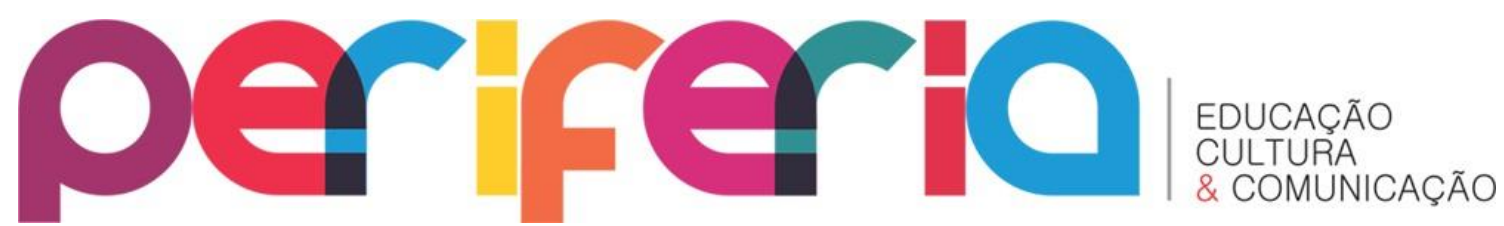

\title{
JOÃOZINHO DA GOMÉIA E O INSTITUTO HISTÓRICO DA CMDC: ACERVO, MEMÓRIAS E PATRIMÔNIO
}

\author{
Tania Maria da Silva Amaro de Almeida ${ }^{1}$ \\ Antonio Augusto Braz ${ }^{2}$
}

\section{RESUMO}

O Instituto Histórico da Câmara Municipal de Duque de Caxias foi fundado em 1973. Desde então, tem se destacado na guarda do acervo histórico de Duque de Caxias e da Baixada Fluminense. Entre os mais de setenta mil itens documentais - reproduções fotográficas, documentos originais, livros e jornais -, o acervo do babalorixá Joãozinho da Goméia destaca-se entre publicações bibliográficas, reportagens de jornais, vestimentas e artefatos religiosos. A Revista Pilares da História, publicação editada pelo Instituto Histórico desde o ano 2002, conta com vários artigos sobre Joãozinho da Goméia, bem como o salão de exposições já contou com diferentes mostras artísticas e históricas sobre o mais famoso sacerdote das religiões afro-brasileiras da Baixada Fluminense. 0 presente artigo tem por objetivos identificar, descrever e problematizar o acervo guardado no Instituto Histórico, bem como os seus diferentes usos realizados pelos pesquisadores que buscam o IHCMDC para investigar sobre a trajetória e os diferentes aspectos da vida de Joãozinho da Goméia.

Palavras-chave: Instituto Histórico; Goméia; Preservação; Memória; Patrimônio.

\footnotetext{
1 Doutora em Humanidades, Culturas e Artes pela Unigranrio (2017). Mestre em Letras e Ciências Humanas pela Unigranrio (2012). Possui graduação em Licenciatura (1988) e Bacharelado em História (1992) pela Universidade do Estado do Rio de Janeiro; e, especialização em História das Relações Internacionais pela mesma Universidade. Docente da rede estadual de ensino. Atuou como docente nos Cursos de Graduação em História da Feuduc e Unigranrio. Integra como historiadora/pesquisadora a Comissão para os Bens Culturais e Artes Sacras da Diocese de Duque de Caxias. É diretora do Instituto Histórico da Câmara Municipal de Duque de Caxias e diretora de pesquisa da Associação dos Amigos do Instituto Histórico. ORCID iD: http://orcid.org/0000-0002-2042-2978. E-mail: taniaamaroalmeida@gmail.com

${ }^{2}$ Mestre em História Social do Brasil pela Universidade Severino Sombra. Licenciatura em História pela FEUDUC; e, especialização em História Social do Brasil pela mesma faculdade. Docente da rede municipal de ensino. Atuou como docente nos Cursos de Graduação em História da Feuduc e Unigranrio. Membro do corpo editorial da Revista Pilares da História e sócio fundador da Associação de Amigos do Instituto Histórico. Sócio fundador emérito da Associação de Professores-Pesquisadores de História-Clio. Diretor do CRPH-Museu Vivo do São Bento. E-mail: augusto.museuvivo@gmail.com
}

Periferia, v. 12, n. 3, p. 129-153, set./dez. 2020 


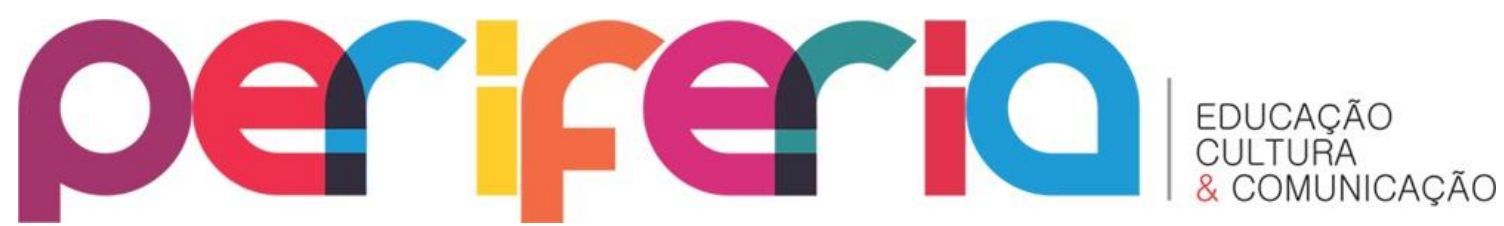

ISSN:1984-9540

DOI: $10.12957 /$ periferia.2020.55035

\section{JOÃOZINHO DA GOMÉIA AND THE INSTITUTO HISTÓRICO CMDC: COLLECTION, MEMORIES AND HERITAGE}

\section{ABSTRACT}

The Instituto Histórico da Câmara Municipal de Duque de Caxias was founded in 1973. Since then, it has stood out in the guard of the historical collection of Duque de Caxias and Baixada Fluminense. Among the more than seventy thousand documentary items - photographic reproductions, original documents, books and newspapers - the collection of the babalorixá Joãozinho da Goméia stands out among bibliographic publications, newspaper reports, clothing and religious artifacts. The magazine Pilares da História, published by the Instituto Histórico since 2002, has several articles on Joãozinho da Goméia, as well as the exhibition hall with different artistic and historical exhibitions about the most famous priest of Afro-Brazilian religions in Baixada Fluminense. This article aims to identify, describe and problematize the collection of Instituto Histórico, as well as its different uses made by researchers who seek the IHCMDC to investigate the trajectory and different aspects of Joãozinho da Goméia's life.

Key-words: Instituto Histórico; Goméia; Preservation; Memory; Patrimony.

\section{JOÃOZINHO DA GOMÉIA Y EL INSTITUTO HISTÓRICO CMDC: COLECCIÓN, MEMORIAS Y PATRIMONIO}

\section{RESUMEN}

El Instituto Histórico da Câmara Municipal de Duque de Caxias fue fundado en 1973. Desde entonces, ha destacado en la custodia de la colección histórica de Duque de Caxias y Baixada Fluminense. Entre los más de setenta mil elementos documentales - reproducciones fotográficas, documentos originales, libros y periódicos - destaca la colección del babalorixá Joãozinho da Goméia entre publicaciones bibliográficas, reportajes periodísticos, indumentaria y artefactos religiosos. La revista Pilares da História, publicada por el Instituto Histórico desde 2002, tiene varios artículos sobre Joãozinho da Goméia, así como la sala de exposiciones con diferentes exposiciones artísticas e históricas sobre el sacerdote de religiones afrobrasileñas más famoso del Baixada Fluminense. El presente artículo tiene como objetivo identificar, describir y problematizar la colección que se conserva en el Instituto Histórico, así como los diferentes usos que hacen los investigadores que buscan el IHCMDC para investigar la trayectoria y diferentes aspectos de la vida de Joãozinho da Goméia.

Palabras clave: Instituto Histórico; Goméia; Preservación; Memoria; Patrimonio. 


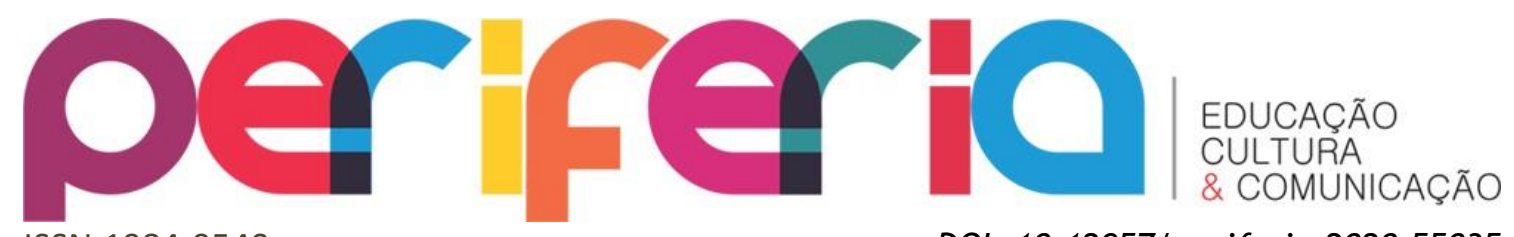

ISSN:1984-9540

DOI: $10.12957 /$ periferia.2020.55035

\section{INTRODUÇÃO}

Ainda nos dias atuais, muitos questionam por que preservar 0 patrimônio histórico e cultural? Quais motivos devem nortear a conservação de objetos ou construções que podem, para muitos, parecer velhos e sem utilidade? Por que não substituí-los pelo "novo"?

A esses questionamentos, o Instituto Histórico da Câmara Municipal de Duque de Caxias, a partir do processo de revitalização que tomou conta do espaço nos anos 2000, junto às atividades de preservação que foram instituídas naquele momento, sempre buscou responder com o incentivo às pesquisas, exposições e atividades que se desdobrassem em estratégias relacionadas à divulgação da cultura e do patrimônio no município de Duque de Caxias.

0 "novo" pode e deve se utilizar do passado para que as memórias nos remetam à construção de uma cidadania participativa, pois, o distanciamento e o desconhecimento das heranças de gerações passadas, acabam por gerar a desvalorização e a não preservação do patrimônio cultural que nos representam hoje.

A história ainda herdeira de uma tradição que afirma somente os grandes feitos da história e memória oficiais, mantém no esquecimento o cidadão comum que colaborou na sua construção. Reconhecer-se como sujeito de sua própria história, que é produtor de saberes e portador de memórias, requer um trabalho contínuo de educação patrimonial na cidade.

Os lugares de memória de uma cidade são também lugares de história. História e memória são, ambas, narrativas do passado que presentificam uma ausência, reconfigurando uma temporalidade escoada. São representações que dão a ver um "acontecido" que, a rigor, não é mais verificável ou sujeito à repetição. Mas o tempo passado não é irrecuperável, uma vez que, através do imaginário, se faz presente no espírito, dando-se a ler e ver através de discursos e imagens. Uma cidade é, pois, detentora de história e memória, assim como também o é desta comunidade simbólica de sentido a que se dá o nome de identidade. 0 centro de uma cidade foi, por muito tempo, o cartão de visitas de uma cidade. Mesmo que 


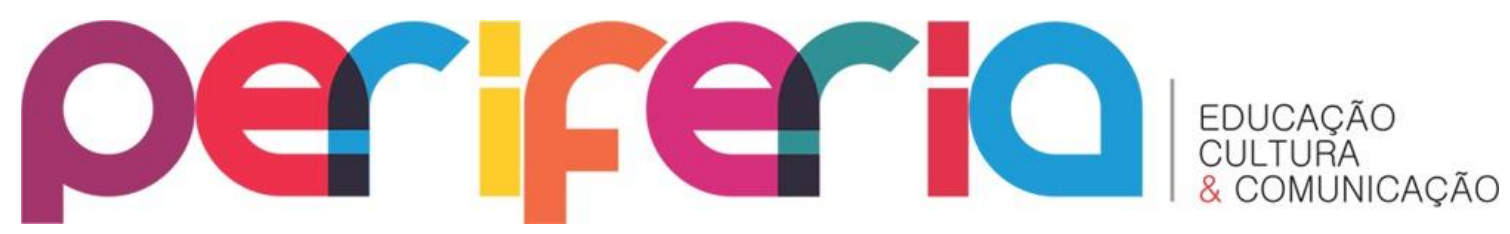

tais espaços tenham sofrido degradação, deixaram marcas, que funcionam como padrões de referência identitária para uma cidade. (PESAVENTO, 2008. p. 2)

Toda cidade tem muitas histórias, que se transformam através do tempo e por meio da ocupação dos espaços pelo homem. São muitas as formas de contá-las. Essas histórias estão presentes na cultura do povo, no desenvolvimento econômico e social, nas obras e objetos deixados por cidadãos, sejam ilustres ou não, e também nas edificações, memórias visíveis da evolução urbana.

Buscamos, com este artigo, refletir sobre o quanto a proteção ao nosso patrimônio conduz à recuperação da memória cultural, sendo uma das formas mais significativas para a reconstrução de nossa história, neste caso específico, a partir da identificação do acervo salvaguardado no Instituto Histórico da Câmara Municipal de Duque de Caxias, na Coleção Joãozinho da Goméia. Entre os itens que integram a referida coleção do famoso babalorixá, destacam-se peças nos mais variados suportes, que tem seus usos estudados por pesquisadores que buscaram o IHCMDC para investigar sobre a trajetória e os diferentes aspectos da vida de Joãozinho da Goméia.

\section{O INSTITUTO HISTÓRICO DA CMDC}

O Instituto Histórico da Câmara Municipal de Duque de Caxias completou 47 anos de criação no dia 31 de janeiro de 2020. 0 espaço tornouse referência de acesso às pesquisas relacionadas com a região do entorno da Baía de Guanabara a partir do início dos anos 2000, quando atividades de revitalização foram implementadas pelo poder legislativo.

O IHCMDC originou-se da necessidade que a antiga Biblioteca José do Patrocínio, então situada no $3^{\circ}$ andar do prédio da Câmara, sentia de atender seus leitores mais interessados em conhecer o passado do município. A ideia surgiu no início da década de 1970, a partir da professora Dalva Lazaroni e de seu irmão, o então diretor geral da Câmara e ex-vereador, Elias Lazaroni. 


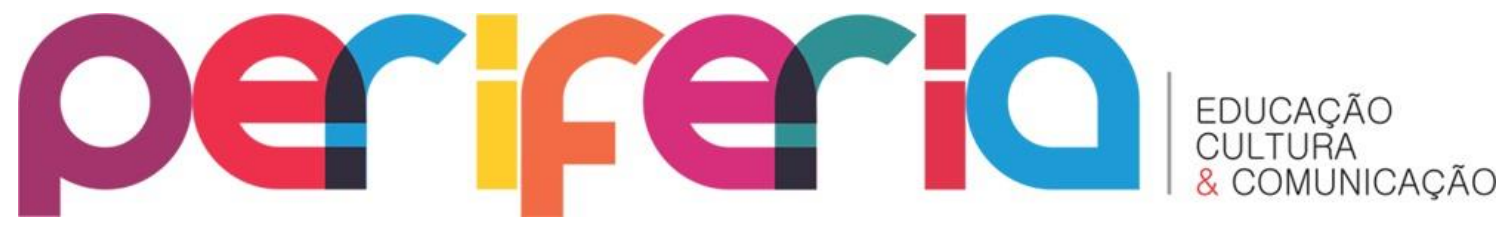

ISSN:1984-9540

DOI: $10.12957 /$ periferia.2020.55035

Inaugurado como órgão anexo à Câmara Municipal, no ano de 1973, com o nome de Instituto Histórico e Geográfico de Duque de Caxias, passou a ser denominado Instituto Histórico Vereador Thomé Siqueira Barreto, através da Resolução 494, de 11 de dezembro de 1980.

Resolução $\mathrm{n}^{\circ}$ 494, de 11 de dezembro de 1980. / A Câmara Municipal de Duque de Caxias decreta e eu promulgo a seguinte Resolução: / Art. $1^{\circ}$ - Fica denominado Instituto Histórico "Vereador Thomé Siqueira Barreto" o atual Instituto Histórico, órgão anexo à Câmara. / Art. $2^{\circ}$ - A presente Resolução entrará em vigor na data de sua publicação, revogadas as disposições em contrário. / Câmara Municipal de Duque de Caxias, em 11 de dezembro de 1980. / José dos Santos Callado / Presidente.

Projeto de Resolução $n^{\circ}$ 94/80.

Considerando que o Sr. THOMÉ SIQUEIRA BARRETO foi eleito Vereador pela primeira vez em 1959; / Considerando sua reeleição; a última em 1977 quando exerceu a função até novembro de 1980 quando vem a falecer; / Considerando que por várias vezes pertenceu às Comissões Técnicas do Poder Legislativo Duquecaxiense; / Considerando que na qualidade de comerciante, em Gramacho, muito trabalhou pela sua gente, como pelo engrandecimento do local; / Considerando o homem querido que era por seus amigos, colegas e admiradores; / Considerando que como Vereador prestigiou grandemente o Município em todas as obras de vulto a citar sua colaboração no erguimento do Instituto Histórico, órgão ligado à Câmara Municipal; / Considerando o exemplo de cidadão honrado, trabalhador, chefe de família exemplar, estimado, querido de todos, / A Câmara Municipal de Duque de Caxias decreta e eu promulgo a seguinte Resolução: / Art. $1^{\circ}$ - Fica denominado Instituto Histórico "Vereador Thomé Siqueira Barreto" o atual Instituto Histórico, órgão anexo à Câmara; / Art. $2^{\circ}$ - A presente Resolução entrará em vigor, na data de sua publicação, revogadas as disposições em contrário. / Secretaria, em $1^{\circ}$ de dezembro de 1980. / Vereador Vilson Macedo - Autor. (CMDC, acervo IH)

Os institutos históricos e geográficos foram pioneiros no recolhimento e na sistematização da documentação histórica, em levantamentos geográficos e em estudos etnográficos e linguísticos. Vistos com certo preconceito, 


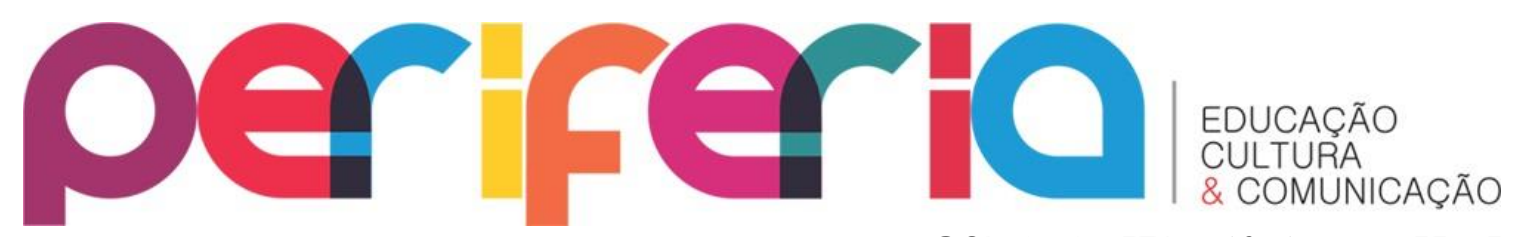

ISSN:1984-9540

DOI: $10.12957 /$ periferia.2020.55035

durante anos, por determinados setores da comunidade acadêmica, os institutos foram responsáveis pela produção de um saber próprio no momento em que a separação entre campos diversos do conhecimento estava se delineando, enquanto a história reivindicava para si um estatuto científico, embasado pela pesquisa documental.

Durante muitos anos, o Instituto Histórico e Geográfico Brasileiro (IHGB) era o único expoente da produção do saber histórico. O IHGB surgiu, em 1838, da aspiração por uma entidade que refletisse a nação brasileira que, não muito antes, conquistara a sua independência, contando com subvenção oficial e intervenção pessoal do próprio imperador nos seus 50 primeiros anos. $^{3}$

A essa instituição pioneira, seguiu-se a constituição do Instituto Arqueológico e Geográfico Pernambucano (IAGP), no ano de 1862, com acentuada preocupação regional. Posteriormente, novos institutos com base local começaram a ser inaugurados, seguindo o modelo proposto pelo IHGB, mas também buscando realçar aspectos da história local, salientando a importância da região na composição da história nacional (CALLARI, 2001, p. $60)$.

A partir da década de 1960, então na Baixada Fluminense, surgiram o Instituto Histórico e Geográfico de Nova Iguaçu (ARAÚJO, 2011, p. 97), fundado em 15 de novembro de 1962; o Instituto Histórico e Geográfico de Duque de Caxias, este ligado à Câmara de Vereadores; e, o Instituto Histórico e Geográfico de São João de Meriti, fundado em 24 de julho de $1991 .{ }^{4}$

Fonte de estudos obrigatória para muitos pesquisadores, o atual Instituto Histórico da Câmara Municipal de Duque de Caxias é responsável pela guarda de fotografias, documentos e objetos que se originaram de doações feitas por pessoas e instituições, e que fazem parte de um referencial significativo para a história do município de Duque de Caxias e também da Baixada Fluminense.

\footnotetext{
3 IHGB, http://www.ihgb.org.br/

${ }^{4}$ Mapa de Cultura RJ, http://mapadecultura.rj.gov.br/
}

Periferia, v. 12, n. 3, p. 129-153, set./dez. 2020 


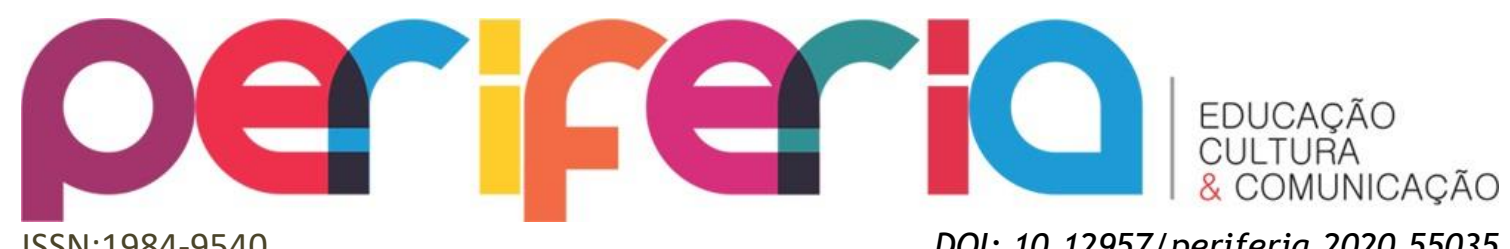

ISSN:1984-9540

DOI: $10.12957 /$ periferia.2020.55035

No início de 2001, surgiu a proposta de desenvolver um projeto de preservação, a fim de que fosse realizado um trabalho sistemático e integrado de conservação e processamento técnico do acervo. Uma análise preliminar do acervo em questão mostrou que ele se encontrava em processo de degradação crescente, em decorrência das agressões sofridas durante anos, carecendo de um processamento técnico adequado para levantamento e catalogação do mesmo em quantidade e qualidade reais, além de um tratamento de preservação para não se deteriorar ainda mais e permitir, assim, a contenção dos danos presentes.

Por meio das atividades realizadas desde então, coordenadas por uma historiadora e especialista em preservação de acervos, os processos de higienização, primeiras recatalogações, pré-arranjos e levantamento quantitativo tornaram-se constantes, levando a possibilidade de se verificar que o acervo do Instituto Histórico é hoje constituído por cerca de 70.000 itens documentais, entre reproduções fotográficas e filmográficas; documentos textuais; livros; periódicos, entre jornais e revistas; plantas de loteamentos; quadros, pinturas e pôsteres; além de objetos de uso pessoal e vestuário - alguns deles expostos em uma mostra permanente para o público interessado.

Além disso, o acervo recebe, frequentemente, doações de periódicos e outros itens documentais relativos à nossa história local e regional, sendo também parte integrante do espaço físico do Instituto, as galerias de fotos dos prefeitos, presidentes do poder Legislativo e diretores da Câmara Municipal. Assim, a cada relatório elaborado periodicamente, constata-se também que o desdobramento e continuidade das atividades demonstram a real extensão deste acervo tão importante para a história local e regional do município e da Baixada Fluminense.

O Instituto Histórico da CMDC, apesar de ser uma instituição do poder público, atualmente deve parte de sua importância à Associação dos Amigos do Instituto Histórico (ASAMIH), bem como à relação com outras instituições 


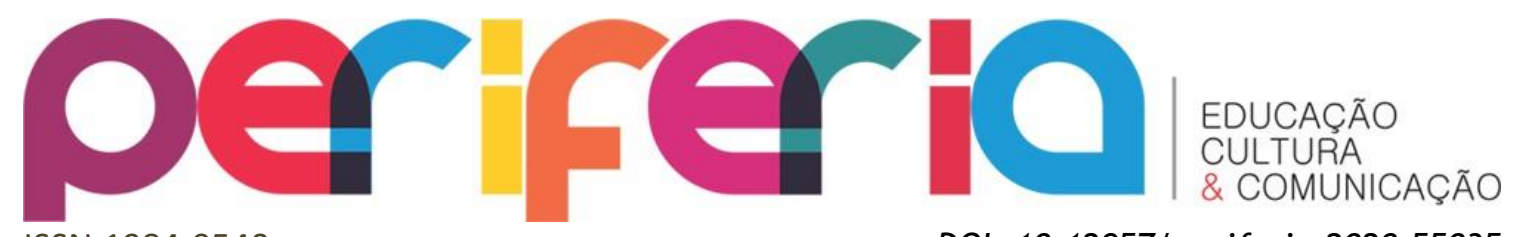

que se configuram em uma rede de pesquisas relacionadas à Baixada Fluminense.

A criação da Associação dos Amigos foi proposta, a partir de junho de 2001, visando uma maior participação dos setores organizados da sociedade e, consequentemente, promovendo uma maior divulgação do órgão. Entidade sem fins lucrativos, consta de seu estatuto, aprovado pelos sócios intelectuais, pesquisadores e cidadãos que manifestam interesse pela cultura e história -, o estabelecimento de intercâmbio com outras associações e entidades afins e o incentivo à integração cultural com a comunidade. Como entre suas finalidades também estão o apoio a programas de processamento técnico e conservação das obras, incentivo às exposições e busca de captação de recursos financeiros para a instalação de projetos culturais, a ASAMIH foi contemplada em edital pelo governo do Estado do Rio de Janeiro em 2008, sendo considerada, desde então, um Ponto de Cultura, com o projeto “Tecendo as Ações no Presente. Construindo a Cidadania do Futuro", por meio do qual apoiou a realização de várias atividades culturais.

Destacamos isso, pois a marca dos Institutos Históricos é serem instituições da sociedade civil, ainda que muitos tenham como base de financiamento parcerias com o poder público. Isto se torna importante para a reflexão sobre os modelos dos Institutos Históricos.

No Instituto Histórico da CMDC, nota-se a participação da Associação dos Amigos e de seus sócios em várias atividades, com a integração, diálogo e consenso da direção do espaço, exatamente devido ao mesmo ser um órgão do Poder Legislativo, não possuindo verba própria destinada a ele. Além disso, na região da Baixada Fluminense, há uma rede de memória, história e patrimônio atuante, que tem também colaborado, o que demonstra que o IHCMDC é uma instância de participação da sociedade civil e deve ser compreendido na relação com sua Associação de Amigos e parcerias, o que revela a densidade do trabalho de memória que é feito na região.

Outro ponto importante das atividades realizadas pelo IHCMDC, na relação com as pesquisas e preservação dos acervos arquivístico e 


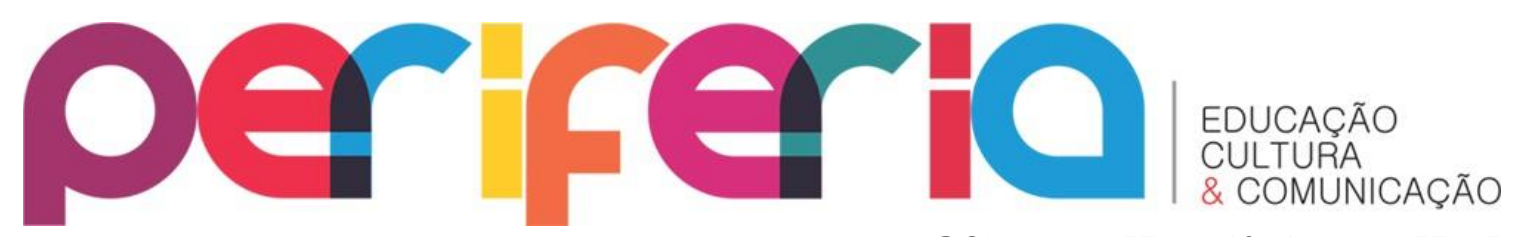

bibliográfico, é que os documentos catalogados, higienizados, devidamente acondicionados e armazenados, possam estar à disposição dos pesquisadores. Entretanto, sob nenhuma hipótese, os itens documentais podem ser retirados do Instituto Histórico, local onde as pesquisas deverão ser realizadas, visando, sobretudo, a salvaguarda das diversas peças constantes do acervo. Para marcar esta importância, foi instituído o ATO n 126/2004, da Mesa Executiva da Câmara Municipal de Duque de Caxias, datado de 15 de dezembro de 2004, que entre as resoluções afirma:

(...) o acervo do Instituto Histórico Vereador Thomé Siqueira Barreto, (...) é público e de acesso livre a qualquer interessado. / Não será permitida a retirada de qualquer objeto pertencente ao acervo do Instituto Histórico (...) / (..) As funções e atividades desempenhadas no Instituto devem ser pautadas pela prioridade no atendimento aos interessados na história do nosso município e da região da Baixada Fluminense, (...) servindo como referência para pesquisas (...). (CMDC, Ato $\left.\mathrm{n}^{\circ} 126 / 2004\right)$.

Assim, nota-se que, por meio das atividades realizadas pelo Instituto Histórico da Câmara Municipal de Duque de Caxias, levando à preservação do nosso patrimônio, potencializa-se a constituição de cidadãos conscientes. Esta afirmação reforça os atuais objetivos do Instituto Histórico, na busca por um maior prolongamento possível dos bens culturais, que conferem identidade e orientação a uma comunidade, inspirando valores ligados à ética, à solidariedade e ao estímulo da cidadania, difundindo identidade com o lugar e contribuindo para garantir o estímulo à memória das pessoas historicamente vinculadas a essa comunidade.

\section{A COLEÇÃO JOÃOZINHO DA GOMÉIA}

Entre os itens que integram o acervo do IHCMDC, ao se iniciar o processo de catalogação e arranjo no ano 2000, surgiu a oportunidade de reunir em uma coleção que foi denominada Joãozinho da Goméia, objetos, roupas e documentos arquivísticos e bibliográficos relacionados a João Alves Torres Filho. 


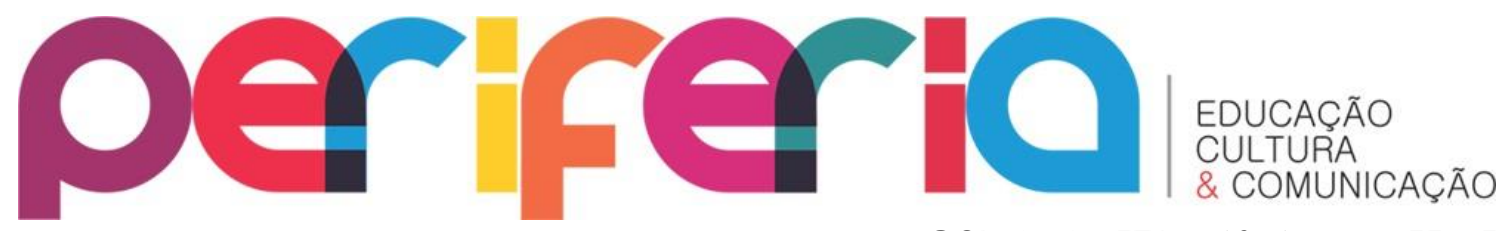

ISSN:1984-9540

DOI: $10.12957 /$ periferia.2020.55035

De acordo com a Revista Memórias da Bahia, publicada pela Universidade Católica de Salvador em dezembro de 2003 e que integra o acervo do IHCMDC, foi "pela cabeça que os orixás trouxeram o menino João Alves Torres Filho para o mundo do candomblé" (p. 10). Aos 10 anos, o garoto nascido em 27 de março de 1914, na cidade de Inhambupe, a 153 quilômetros de Salvador, já havia dado mostras de sua personalidade forte.

Contra a vontade dos pais, deixou a casa da família para tentar a sorte na capital. Teve que se virar para sobreviver, mas contou com o apoio de uma senhora que morava na Liberdade e que considerava sua madrinha. Foi essa senhora que teve a ideia de levá-lo ao terreiro de Severiano Manuel de Abreu, conhecido como Jubiabá. Joãozinho sofria fortes dores de cabeça, que não eram explicadas, nem curadas pelos médicos. Bastou que ele fosse "feito" no candomblé para que as dores fossem embora. Elas seriam somente um aviso dos orixás, que cobravam a iniciação do menino. Essa história é apenas uma das versões existentes sobre a iniciação religiosa de Joãozinho da Goméia.

Mais tarde, seu primeiro terreiro foi num bairro chamado Ladeira de Pedra, mas logo foi para o local que o tornou famoso, incorporando a nome dessa localidade, onde se encontrava a casa, ao seu próprio nome: Goméia. Em 1948, despediu-se de Salvador com uma festa no Teatro Jandaia e mudouse para o Rio de Janeiro. Seguindo para o território da hoje denominada Baixada Fluminense, abriu casa no município de Duque de Caxias, no loteamento Vila Leopoldina, hoje parte do bairro Dr. Laureano.

Waldemar Alvarenga Neto (Reizinho) chama a atenção para o fato de que, pelos idos de 1948, João Alves Torres Filho alugou uma casa na antiga Rua das Vassouras (atual Castro Alves), n 174, no bairro Itatiaia, onde iniciou algumas pessoas em um barracão de madeira no fundo do quintal.

Joãozinho da Goméia ganhava dinheiro com a alfaiataria, costura e dança, além de ser ajudado por suas filhas de Santo, que vendiam comidas típicas da Bahia em tabuleiros.

Nos anos 1950, comprou por 50 mil cruzeiros os lotes 2805, 2806 e 2807, na Rua General Rondon, no loteamento Vila Leopoldina IV (nos mapas, o local e apontado como Vila Leopoldina IV, mas durante anos, os

Periferia, v. 12, n. 3, p. 129-153, set./dez. 2020 


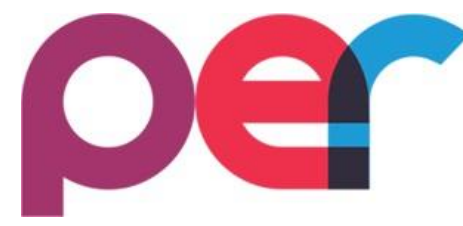

ISSN:1984-9540

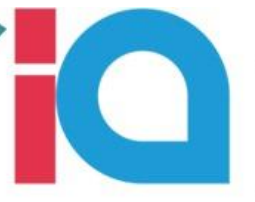

EDUCAÇÃO

CULTURA

\& COMUNICAÇÃO

moradores usavam os nomes das ruas como bairro a exemplo de Rua Copacabana, Rua Jacatirão e Rua Ipanema), onde anteriormente, existia a fazenda Jacatirão. (ALVARENGA NETO, 2008, p. 57)

Anos depois, o trecho da rua onde se localiza o terreiro passou a ser conhecido como Avenida Copacabana. Por meio da lei $\mathrm{n}^{\circ} 191$, de 10 de maio de 1978, mais uma vez, a rua mudou de nome, passando a ser chamada Avenida Prefeito Braulino Reis.

\section{MAPA COM LOCALIZAÇÃO E LIMITES APROXIMADOS DA EDIFICAÇÃO AINDA EXISTENTE NO TERREIRO DE JOÃOZINHO DA GOMÉIA}

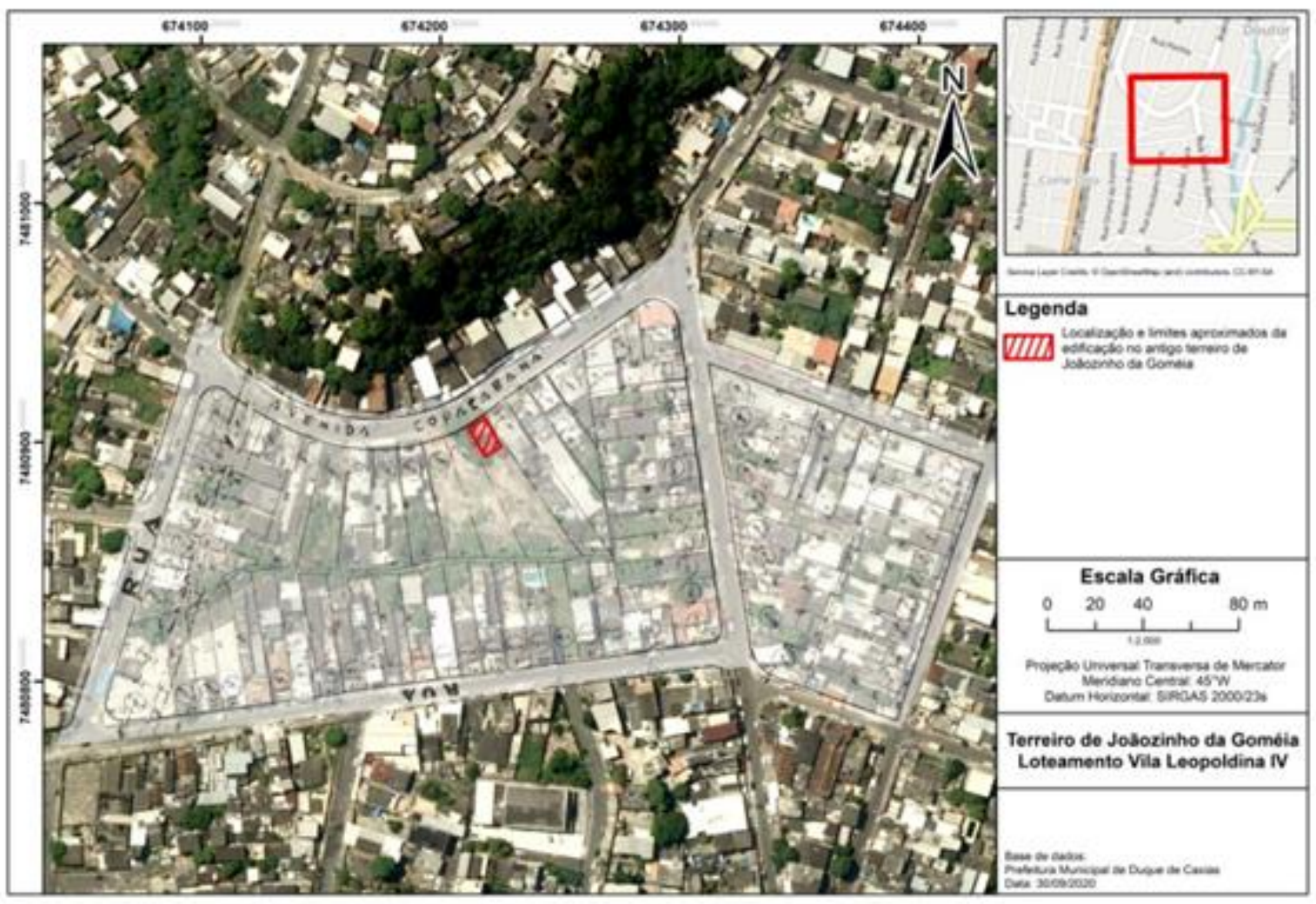

FONTE: ADAPTADO PELOS AUTORES

Ainda, nas décadas de 1950 e 1960, o Terreiro da Goméia passou a ser referência no nosso município, não só por ser um dos primeiros terreiros de Candomblé Angola na região sudeste, mas também por seus frequentadores. Políticos de todos os lugares, entre eles embaixadores da França, Inglaterra e Paraguai, Getúlio Vargas, Henrique Teixeira Lotte, Juscelino Kubitschek, Tenório Cavalcanti; artistas como Cauby Peixoto, Dorival Caymmi, Emilinha 


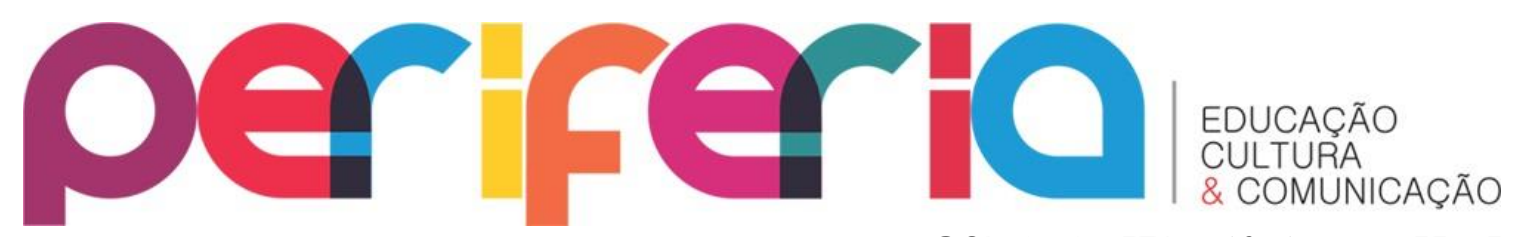

Borba, Francisco Alves, Maria Antonieta Pons, Marlene, Ninon Sevilla, Paulo Gracindo, Solano Trindade; e, nomes relacionados ao candomblé, como José Bispo dos Santos - Pai Bobó, entre outros, frequentavam a Casa de Pai João, trazendo grande popularidade, tornando-o "um grande mediador entre vários segmentos sociais" (NASCIMENTO, 2003, p. 35).

As propagandas das atividades do terreiro da Goméia estampavam as paredes dos mercadinhos e jornais, anunciando distribuição de comida, agasalhos, festas, ensaios e etc...; Joãozinho da Goméia patrocinava festas, enterros, remédios; realizava partos, pagava aluguéis e chegou a sustentar mais de 20 pessoas na sua casa.

Pai João da Goméia era famoso, querido por seus filhos, consultado por pessoas importantes e, inegavelmente, um sucesso. Tristemente, perto de completar 57 anos, sua morte ocorreu em 19 de março de 1971, em São Paulo, devido a uma cirurgia para retirada de um tumor cerebral. A partir de 1950 até os dias atuais, podemos afirmar que foi o pai de santo mais conhecido do país, com fama comparável somente à de Mãe Menininha do Gantois. 

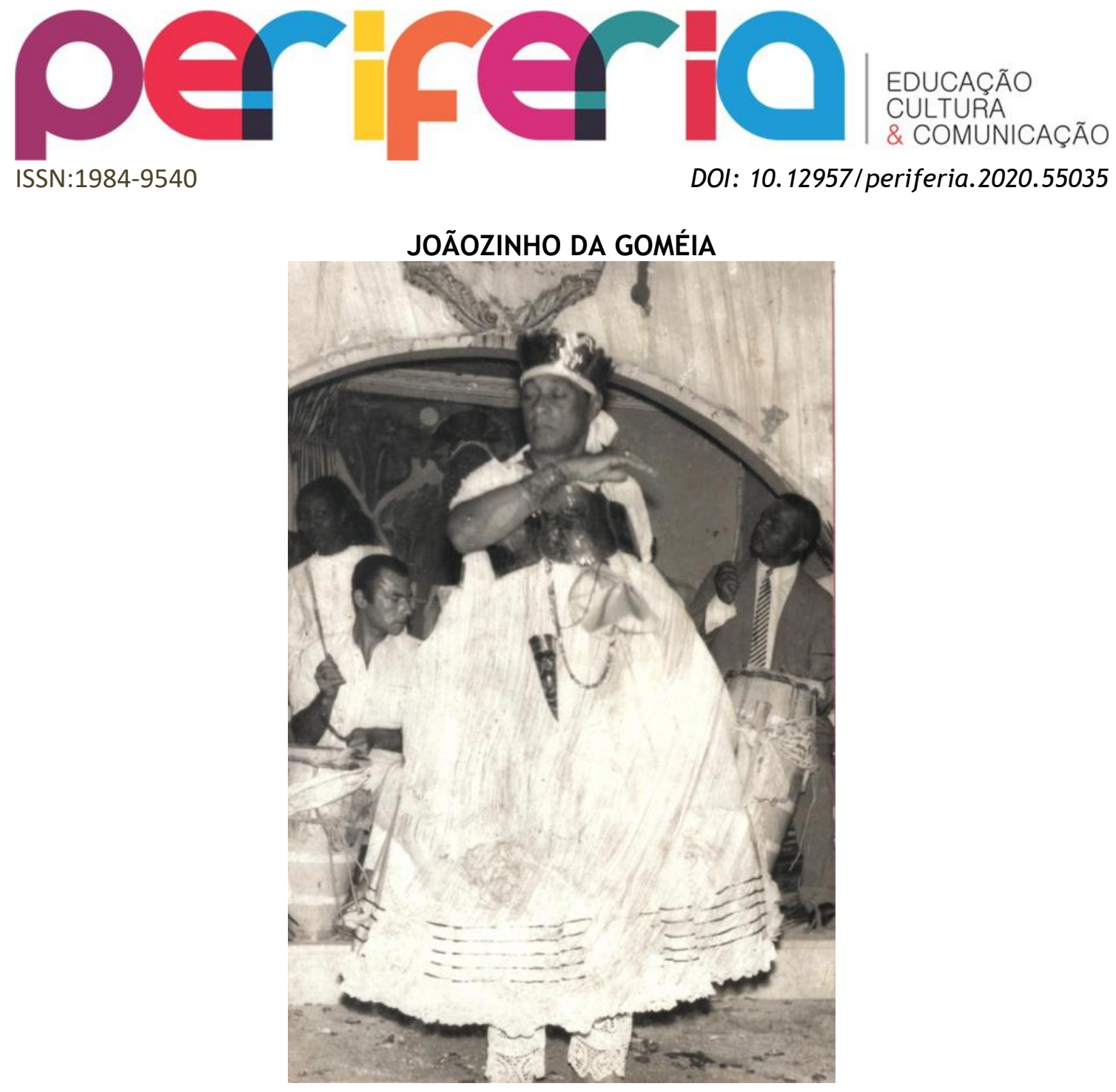

FONTE: ACERVO DO IHCMDC - FOTOGRAFIA: S/D

Sobre a Coleção Joãozinho da Gomeia que integra o acervo do Instituto Histórico, a mesma é organizada a partir das referências documentais, bibliográficas, roupas e objetos de culto.

No acervo do IHCMDC, constam vários livros, pesquisas diversas, revistas e também o resultado das investigações sobre Pai João da Gomeia, em suporte papel e meios digitais, realizadas por vários pesquisadores importantes desse tema, como Andrea Nascimento, Andrea Mendes, Waldemar Alvarenga Neto (Reizinho), Antônio Carlos Peralta, Taís Noronha, Elizabete Gama, Carlos Nobre, Rodrigo Pereira, enfim, são vários livros, dissertações, teses e monografias que nos trazem os mais variados olhares sobre Pai João da Goméia. Encontram-se também vários artigos sobre ele, de autoria de Reizinho, Eldemar de Souza, Guilherme Peres, Rogério Torres, Daniel Isaac, entre outros articulistas, que estão publicados nas edições dos periódicos 


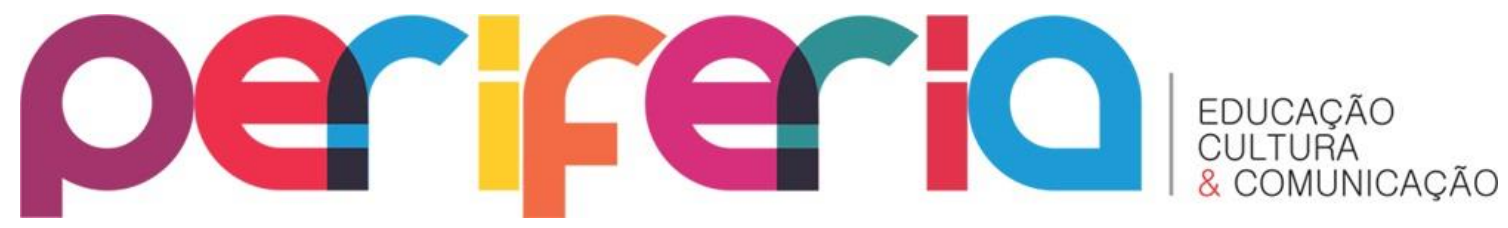

ISSN:1984-9540

DOI: $10.12957 /$ periferia.2020.55035

Revista Caxias Magazine, Memórias da Bahia, Revista da Cultura Caxiense, Revista Pilares da História, esta que pode ser acessada nos sítios da Câmara Municipal de Duque de Caxias e da Associação dos Amigos do Instituto Histórico. ${ }^{5}$

Além de reproduções fotográficas e publicações, o acervo da Coleção Joãozinho da Gomeia inclui roupas e objetos, como o disco longplay com músicas cantadas pelo "Rei do Candomblé - Joãosinho da Goméa"; peças que foram presenteadas a ele, como xícaras, pratos decorativos, bandejas, peso para papel, troféu; além de, objetos de culto, incluindo peças de integrantes da família Gomeia.

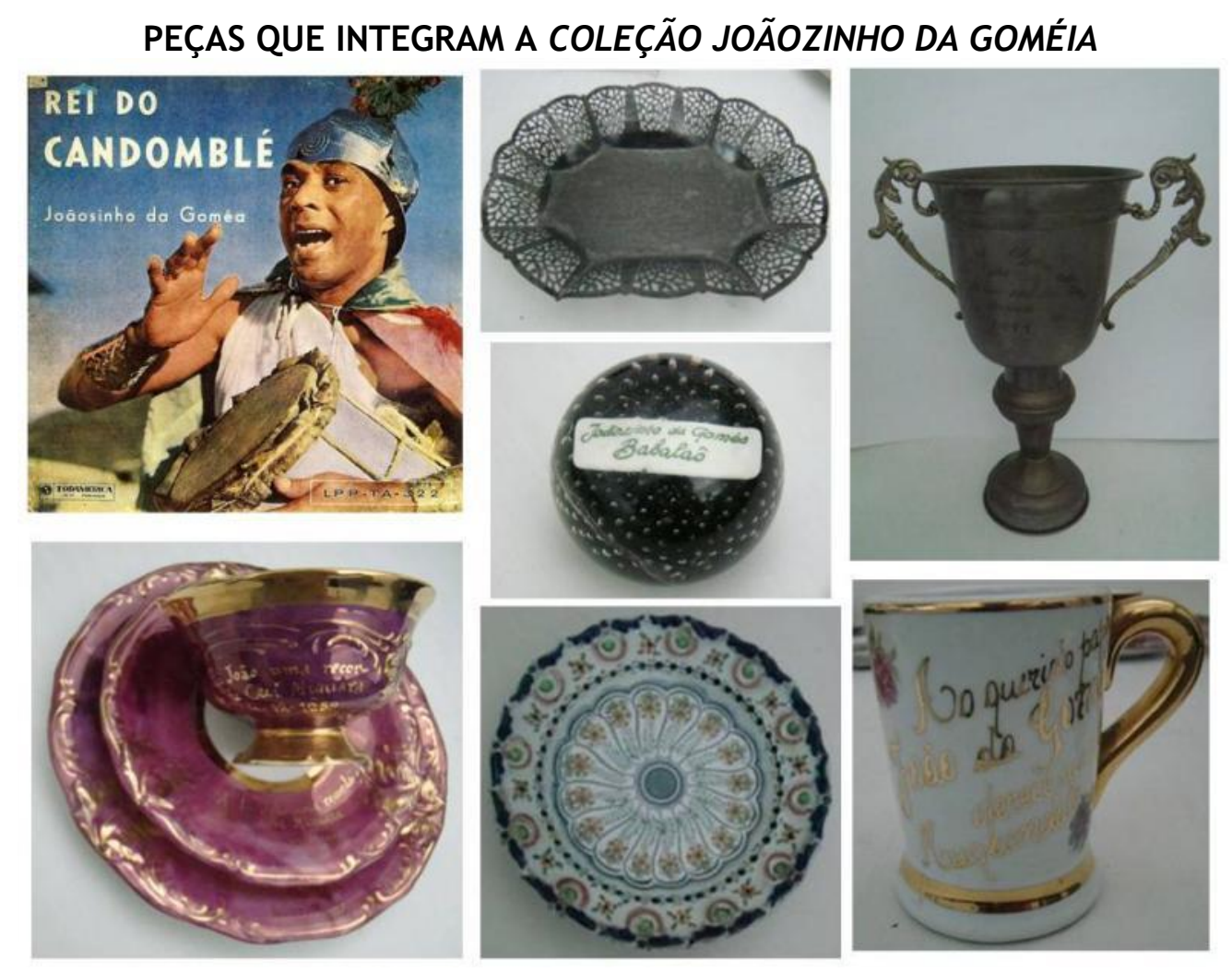

Fonte: Acervo do IHCMDC - Fotografia: Andrea Mendes (2010)

Importante lembrar que esses objetos pessoais e da família, que integram a coleção em questão, foram doadas de forma permanente à Câmara

\footnotetext{
${ }^{5}$ Câmara Municipal de Duque de Caxias: https://www.cmdc.rj.gov.br/?page_id=1474 Associação dos Amigos do Instituto Histórico: http://amigosinstitutohistoricodc.com.br/?page_id=105
}

Periferia, v. 12, n. 3, p. 129-153, set./dez. 2020 


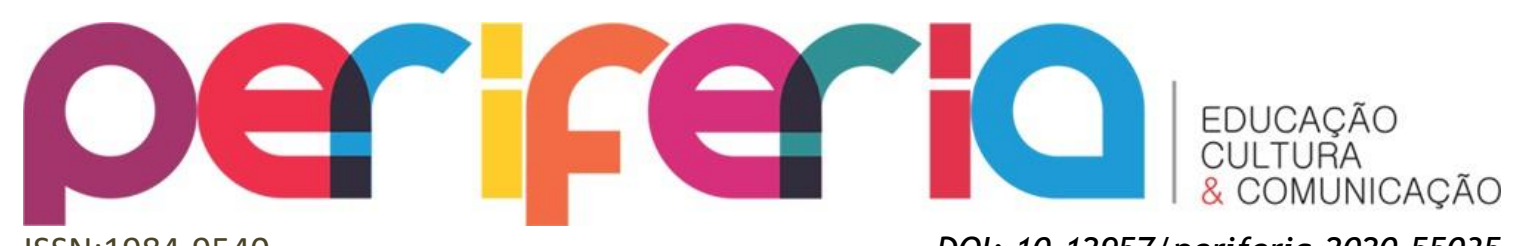

ISSN:1984-9540

DOI: $10.12957 /$ periferia.2020.55035

Municipal de Duque de Caxias, para integrar o acervo do Instituto Histórico, e estão sob a guarda desta instituição desde a década de 1970. A doação das peças ao Instituto Histórico foi efetivada por Mãe llecy, pelo Ogã Antônio Motta e por Mãe Kitala Mungongo, após o falecimento de seu babalorixá. Parte das informações pertinentes ao acervo foi atualizada a partir de esclarecimentos cedidos por Mãe Kitala no período de montagem da Mostra "O Cotidiano e o Sagrado", no ano 2011. Desde então, a partir das informações de Mãe Kitala, de pesquisas de especialistas e de registros fotográficos, a coleção vem passando por novo arranjo arquivístico, com atualização de seus códigos de acesso no acervo do Instituto Histórico.

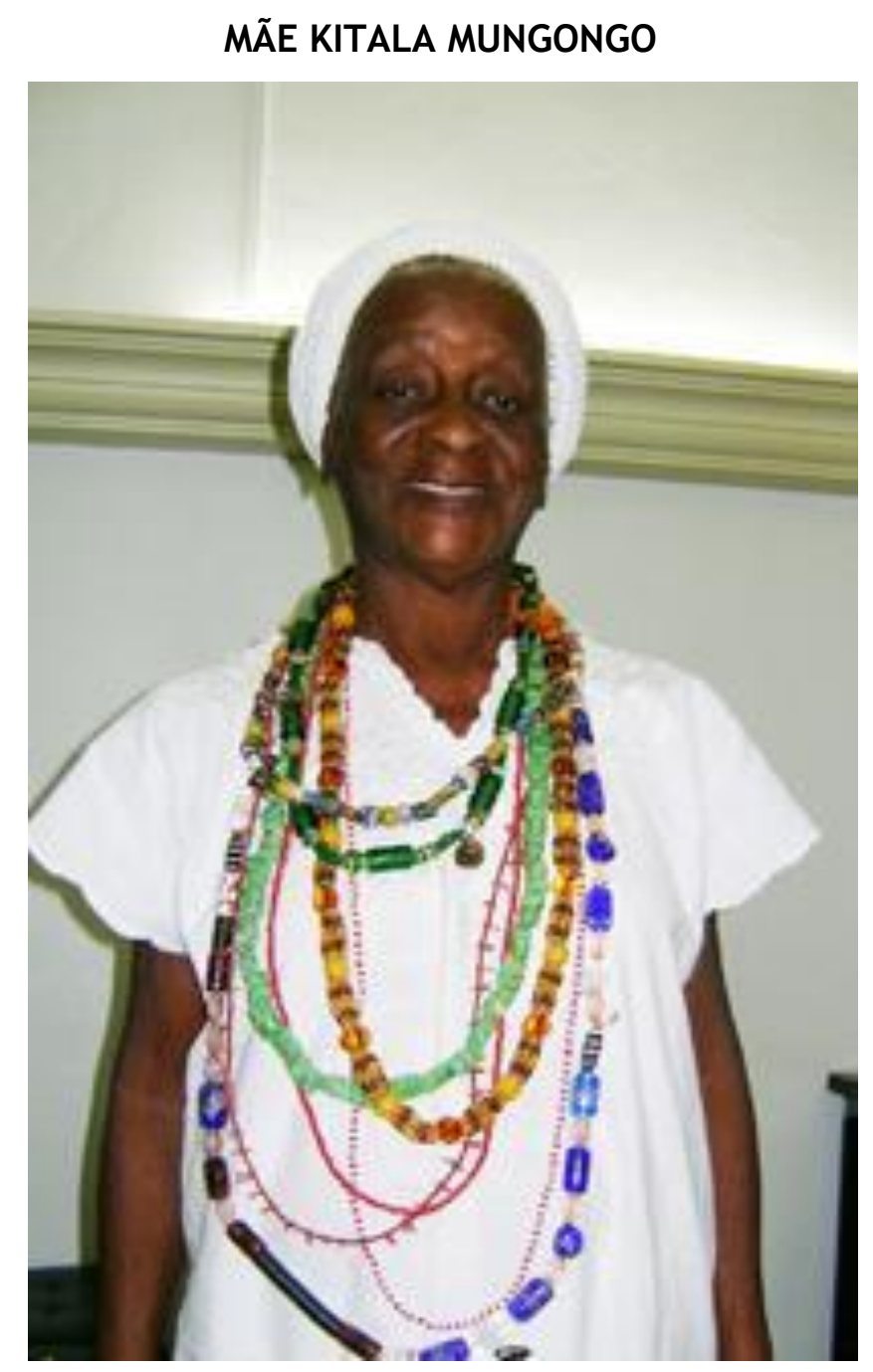

Fonte: Acervo do IHCMDC (2011)

Periferia, v. 12, n. 3, p. 129-153, set./dez. 2020 


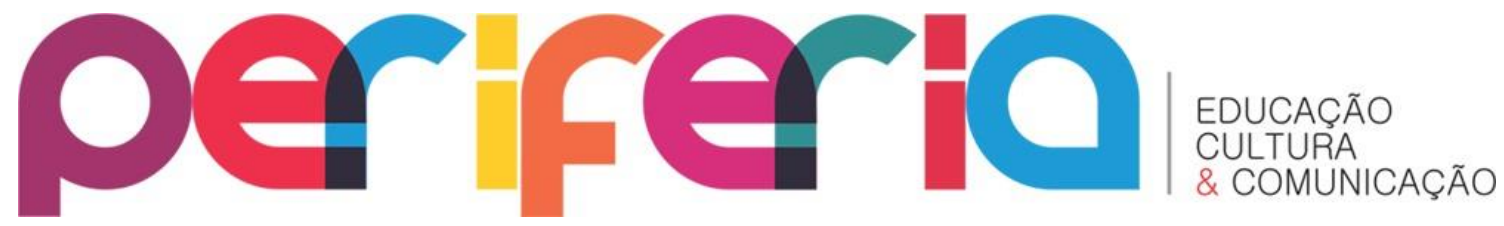

É significativo registrar a participação de Mãe Kitala, no ano de 2011, convidada pela direção do Instituto Histórico, convite intermediado por Waldemar Alvarenga Neto (Reizinho), pois sua presença nos ajudou a identificar algumas das peças que realmente eram de Pai João, ou seja, das quais ele fez uso pessoal. Com o fim de colaborar conosco, Mãe Kitala esteve no Instituto Histórico, colaborando na montagem da mostra "Joãozinho da Goméia: o Cotidiano e o Sagrado em Duque de Caxias", exposição que foi inaugurada no dia 24 de março de 2011, sendo comemorativa pelo Dia Municipal da Cultura, lembrando os 40 anos de morte de Pai João da Goméia.

Roupas e objetos expostos na Mostra

"Joãozinho Da Goméia: O Cotidiano e o Sagrado em Duque de Caxias"

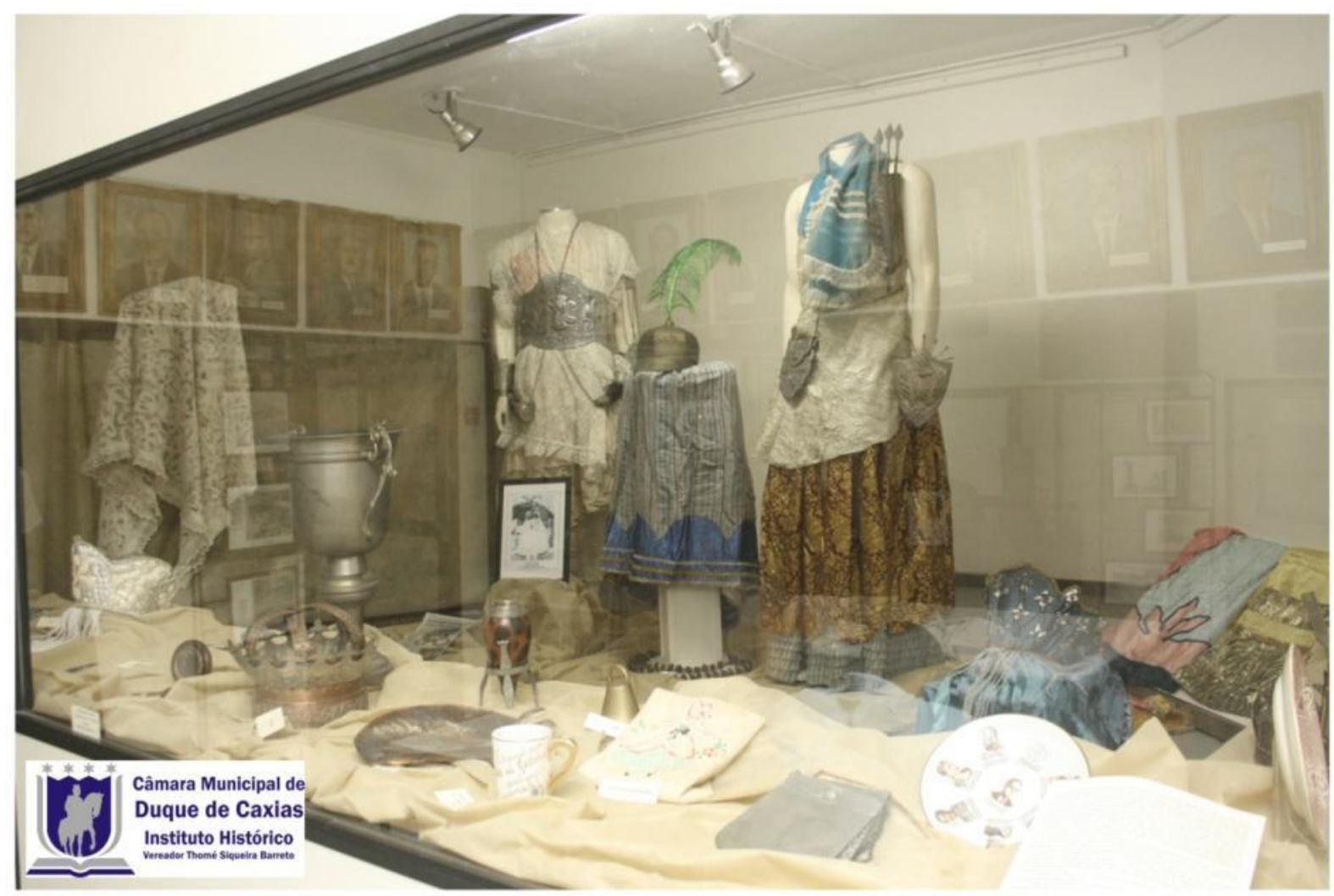

Fonte: Acervo do IHCMDC - Fotografia: Audenir Damião (2011)

Periferia, v. 12, n. 3, p. 129-153, set./dez. 2020 


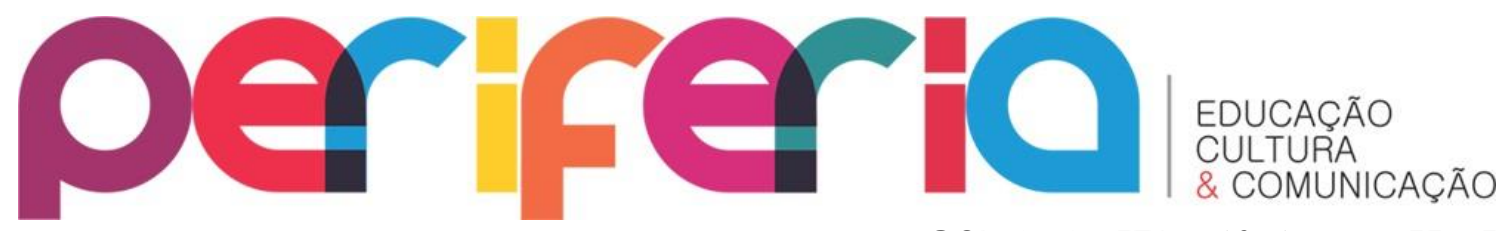

Nessa exposição, estavam objetos, roupas e imagens sobre a vida e a religiosidade de Joãozinho da Goméia e o cotidiano na cidade entre os anos 1940 a 1970. Entre as peças, afirmou Mãe Kitala, há roupas que pertenciam e foram usadas por Pai João da Gomeia, sendo atribuídas a Oxossi e a lansã.

Peças Atribuídas a Oxossi (Coleção Joãozinho da Gomeia)
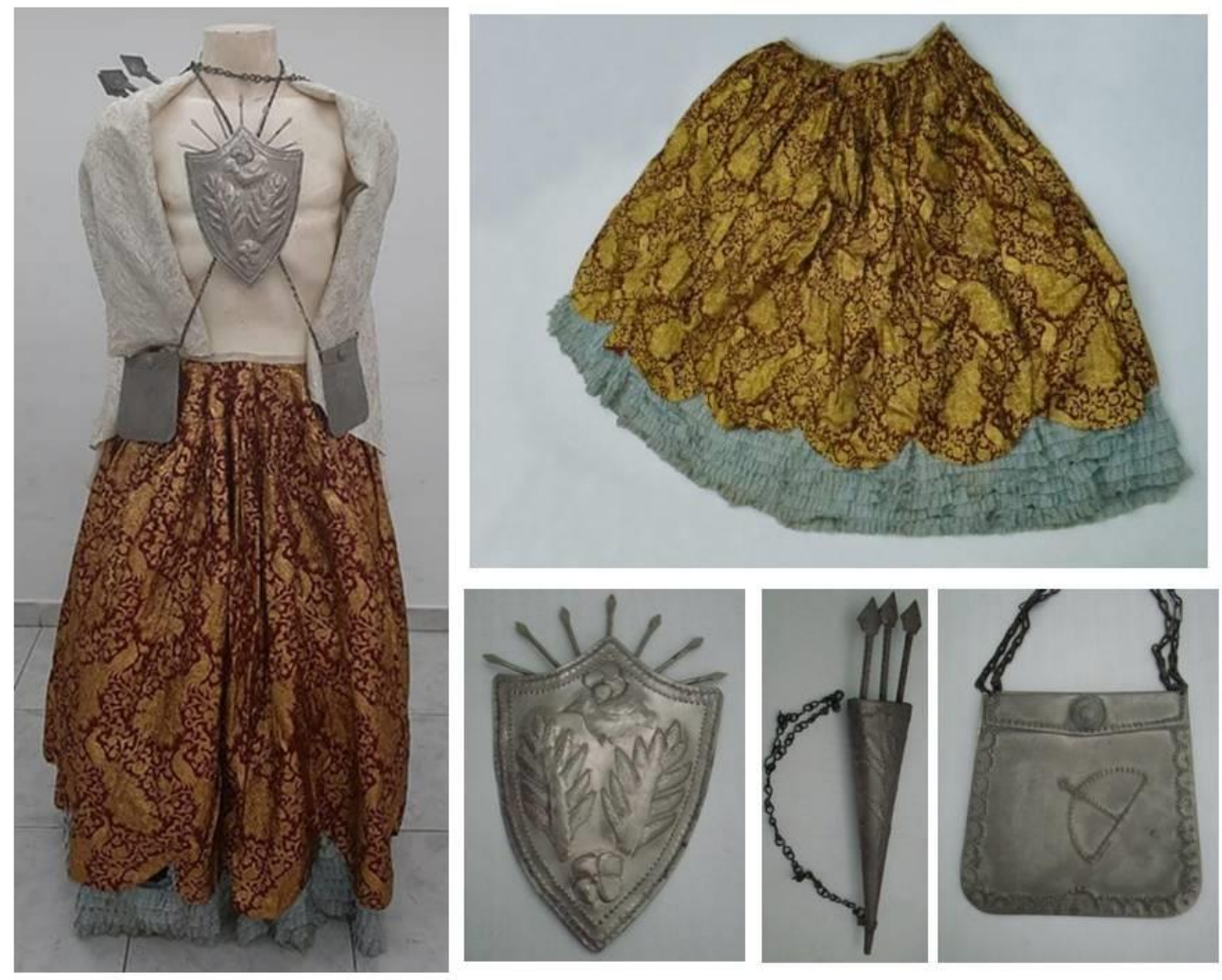

Periferia, v. 12, n. 3, p. 129-153, set./dez. 2020 

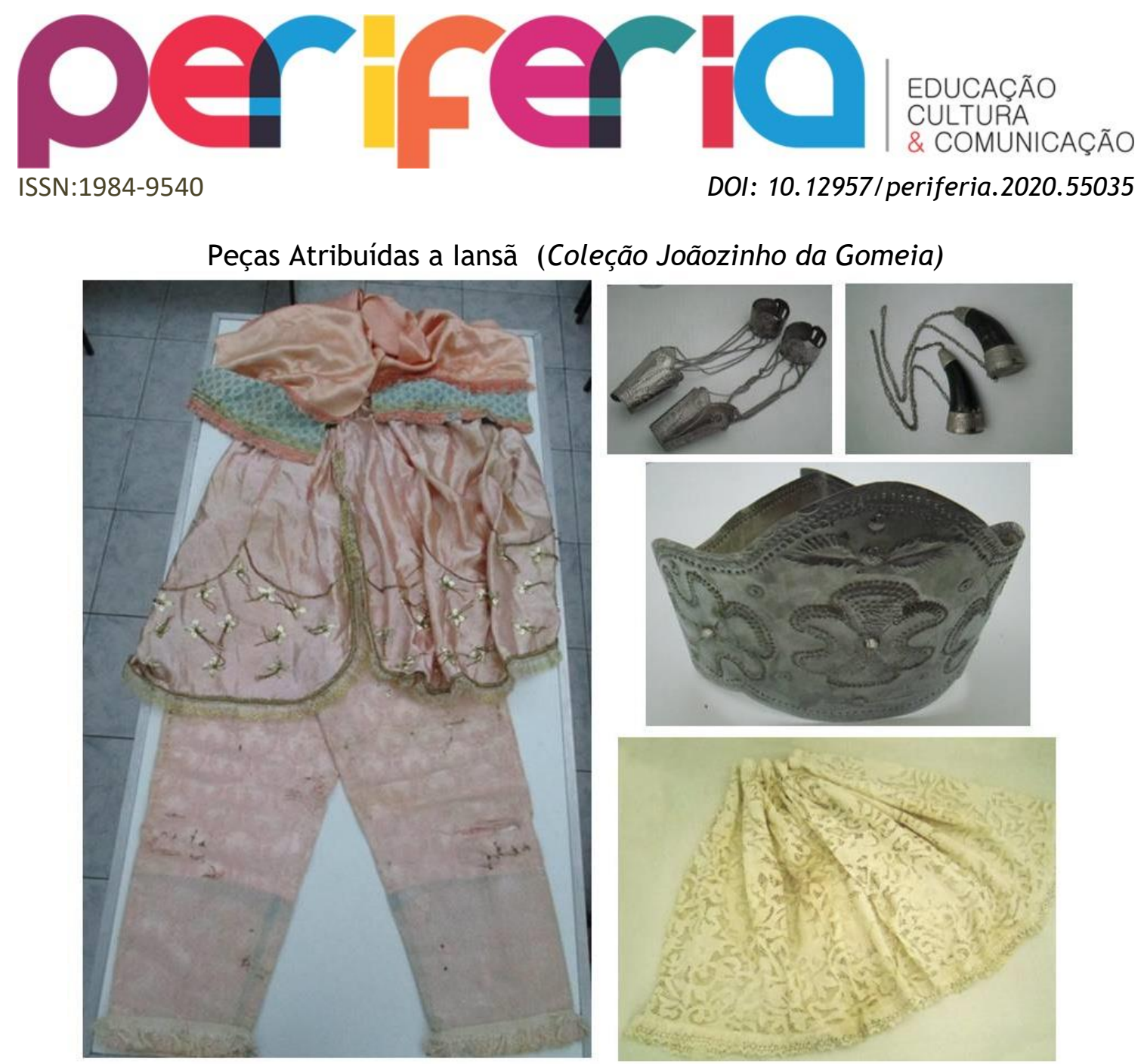

Fonte: Acervo do IHCMDC

Fotografia: Andrea Mendes (2010) e Tania Amaro (2019)

Esses itens documentais são muito pesquisados para trabalhos de mestrado e doutorado, para documentários e curtas-metragens. 0 acervo foi consultado, por exemplo, no ano de 2019, pela equipe da série documental Agbara Dudu: Visionários Negros, dirigido por Silvana Moura. Segundo solicitação enviada ao IHCMDC, o projeto Agbara Dudu é uma série para televisão veiculada na TV Futura, com 13 episódios sobre grandes mulheres e homens da história da cultura brasileira. Para a primeira temporada, 13 sacerdotes foram escolhidos, sete já falecidos: Mãe Senhora de Oxum, Mãe Olga de Alaketu, Mãe Menininha do Gantois, Tia Massi da Casa Branca, Joãozinho da Goméia, Mestre Didi Asipá e Tata Bernardino do Bate Folha; e mais seis vivos: Pai Pecê de Oxumaré, Pai Balbino Daniel de Paula do llê Axé Opô Aganjú, Pai Air do Pilão de Prata, Mãe Raidalva do Terreiro llê Axé Oyá 


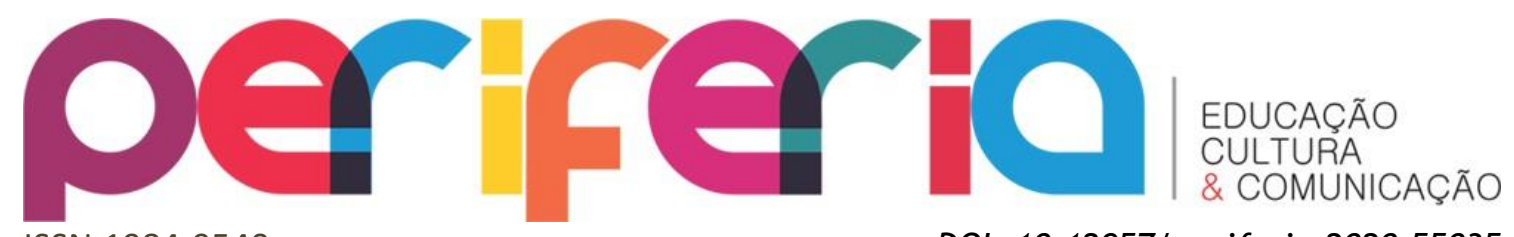

Tolá, Mãe Jaciara do Axé Abassá de Ogum e Mameto Lucia do terreiro São Jorge Filho da Goméia.

Ainda no ano de 2018, a pesquisa no acervo também foi solicitada pelo historiador e cineasta Rodrigo Dutra para projeto de curta-metragem sobre Pai João da Goméia. A pesquisa se concretizou no ano de 2019, sendo utilizado o próprio espaço do Instituto Histórico para montagem do cenário e filmagem do documentário Joãosinho da Goméa - O Rei do Candomblé, dirigido por Janaina Oliveira ReFem e Rodrigo Dutra, tendo Átila Bezerra no papel principal.

Ainda em 2019, os carnavalescos do Grêmio Recreativo Escola de Samba Acadêmicos do Grande Rio consultaram a Coleção Joãozinho da Gomeia. No carnaval de 2020, a Escola ficou com o vice-campeonato, levando poesia para a avenida, no importante tema Tata Londirá - o canto do caboclo no quilombo de Caxias. As pesquisas dos carnavalescos Leonardo Bora e Gabriel Haddad levaram a escola a ganhar o Estandarte de Ouro, prêmio oferecido pelo jornal $O$ Globo, de melhor escola do Grupo Especial do carnaval 2020 e, além do prêmio principal, a agremiação também foi premiada pelo melhor sambaenredo.

Okê! Okê! Oxóssi é caçador / Okê! Arô! Odé! / Na paz de Zambi, ele é Mutalambô! / O Alaketo, guardião do Agueré.

[...]

Salve o candomblé, Eparrei Oyá / Grande Rio é Tatalondirá / Pelo amor de Deus, pelo amor que há na fé / Eu respeito seu amém/ Você respeita o meu axé / (respeita o meu axé).

A Coleção Joãozinho da Gomeia tem significativa contribuição para as pesquisas que tratam da trajetória dessa personalidade da cultura, religião e patrimônio afrodescendentes,

“(...) lembrado sempre por ser um exímio bailarino, por circular nos meios artísticos e políticos com igual desenvoltura, por transformar, em alguma medida, o rito em uma experiência estética (...), por divulgar o

Periferia, v. 12, n. 3, p. 129-153, set./dez. 2020 


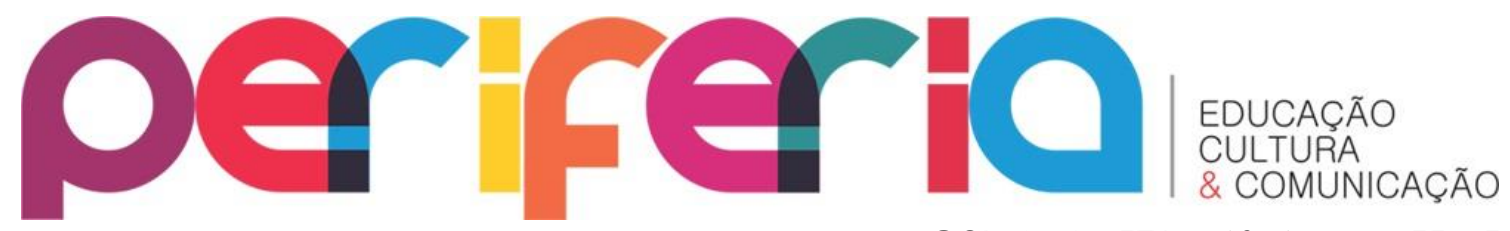

culto na imprensa da época, e por sua paixão pelo carnaval." (MENDES, 2014, p. 121).

O “rei da Goméia duquecaxiense" levou sua Casa a ser um território importante tanto para quem é praticante de religiões de matrizes africanas, como para a comunidade local,

“(...) pois o terreiro de Candomblé significa um espaço que carrega um forte sentido nas questões identitárias, de manifestações culturais e na formação da própria história de uma determinada localidade" (NORONHA, 2017, p. 113).

Dessa forma, acreditamos que as ações de preservação implementadas no Instituto Histórico da CMDC contribuem significativamente para preservação do nosso patrimônio, e possibilitam a constituição de cidadãos conscientes. A busca por um maior prolongamento possível dos bens culturais confere identidade e orientação a uma comunidade, inspirando valores ligados à ética, à solidariedade e ao estímulo da cidadania, difundindo identidade com o lugar e contribuindo para garantir o estímulo à memória das pessoas historicamente vinculadas a essa comunidade.

Foi exatamente esse cuidado no trabalho de preservação que levou o IHCMDC a ser reconhecido com a medalha Joãozinho da Gomeia, concedida à instituição por Mametu Seci Caxi, herdeira de Pai João da Goméia, junto a Wilson Gonçalves, presidente do CONDEDINEPIR - Conselho de Defesa dos Direitos do Negro e Promoção da Igualdade Racial -, em reconhecimento pelo trabalho em prol da memória de Pai João, da defesa e preservação da cultura de matrizes africanas, tema tão importante na atualidade. 


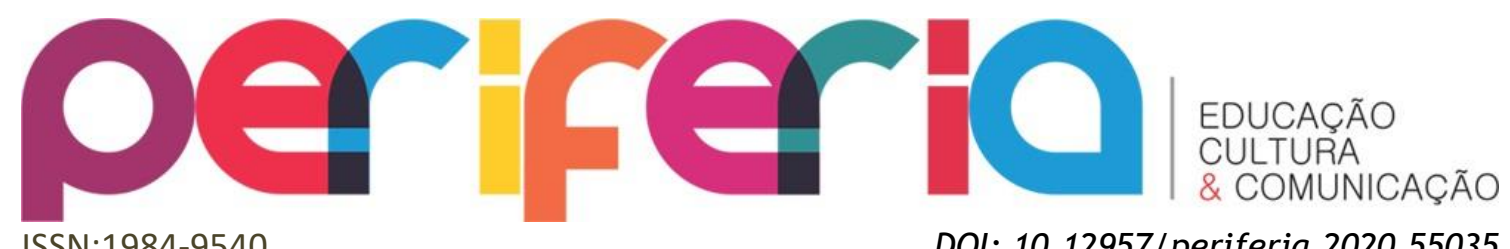

ISSN:1984-9540

DOI: 10.12957/periferia.2020.55035

\section{A IMPORTÂNCIA DA PRESERVAÇÃO PARA MEMÓRIAS E IDENTIDADE}

É muito importante afirmar o quanto é significativo refletir sobre a preservação dos acervos patrimoniais, sobre o quanto essa preservação do patrimônio leva à recuperação da nossa memória cultural, sendo essa a forma mais significativa para a reconstrução da nossa história.

Em muitas instituições públicas e privadas, detentoras de preciosos acervos documentais, a má conservação e a má utilização do material, vêm danificando, ao longo dos anos, e em algumas vezes de forma irreversível, essas peças. Por isso, entre as tarefas prioritárias de uma instituição cultural que visa atender aos que buscam construir a história (no nosso caso, a história do nosso município e da região da Baixada Fluminense) -, devem constar iniciativas ligadas ao aprimoramento das condições de guarda e processamento técnico do acervo, sempre buscando as soluções mais convenientes para a salvaguarda e a recuperação imediata das informações requisitadas.

Preservar uma obra é não permitir que ela seja afetada por fatores externos a ela. Assim, preservação é toda e qualquer atitude de conservação ou de restauração, entendendo-a não só como a perpetuação do bem cultural, mas sim como uma forma de retardar seu processo de deterioração. "A preservação não é um fim em si mesmo. Só preservamos para que as informações contidas nos bens culturais possam favorecer o homem no resgate de sua identidade e de sua história, permitindo, assim, o exercício pleno da sua cidadania" (MUSEU DA REPÚBLICA/ MAST, 1995, p. 15).

Somente com as pesquisas e interesse pela preservação, podemos contribuir para que essas informações contidas nos bens culturais favoreçam as sociedades na recuperação de suas identidades e de sua história, com o objetivo de garantir o exercício pleno da cidadania para todos. Preservar para compreender como se revelam as memórias e identidades, de várias maneiras diferentes, às vezes críticas ou não, mas sempre como forma de valorização do nosso lugar.

Periferia, v. 12, n. 3, p. 129-153, set./dez. 2020 


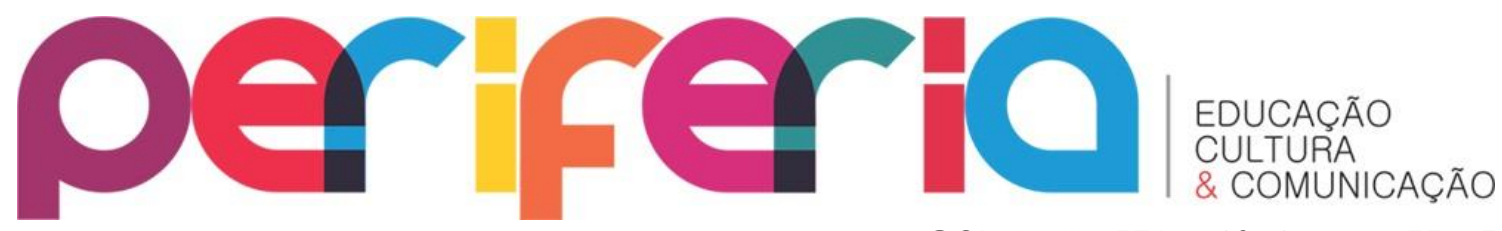

ISSN:1984-9540

DOI: $10.12957 /$ periferia.2020.55035

Toda cidade tem muitas histórias e há muitas formas de contá-las, e as pesquisas tem sido essenciais para colaborar nessa recuperação das informações sobre o nosso território, e nossa cultura. O patrimônio preservado evoca significação para cada fragmento do passado, e reafirmando com Sandra Jatahy Pesavento,

Este é ainda o momento chave no qual a história realiza a construção seletiva da memória, ultrapassando a experiência do vivido e tornando patrimônio comum o que recupera do passado e que se passou há muito tempo atrás. Para tanto, a história se apodera da memória, social e coletiva, e a retrabalha, preenchendo lacunas, dando voz aos silêncios, revelando sentidos e [...] acabando aquilo que, no passado, não ficou concluído. (PESAVENTO, 2005, p. 14)

Nesse sentido, os sujeitos do cotidiano, todos que vivem a cidade, devem estar cientes dos seus deveres. A comunidade é a verdadeira responsável e guardiã de seus valores culturais. Para o interesse da própria comunidade, devem ser pensadas ações de proteção aos bens culturais, pois, à comunidade compete decidir sobre sua destinação no exercício pleno de sua autonomia e cidadania.

Para preservar o patrimônio cultural é necessário, inicialmente, conhecê-lo e para isto, fica clara a emergência da multiplicação de ações educativas que busquem despertar nos sujeitos a "vontade de memória" (NORA, 1993) e a "vontade de patrimônio" (CHAGAS, 2007).

Ações que levem os cidadãos a identificar a história da Baixada Fluminense como espaço fértil que abrigou diferentes experiências de agrupamentos humanos diversos, e que despertem desejos de preservação de seu patrimônio. Além disso, que contribuam para a formação de identidades de grupos e categorias sociais, incorporando a percepção do cotidiano como parte da memória coletiva, permitindo estabelecer elos com os antepassados.

Concordamos com Halbwachs, quando afirma que a memória coletiva é um conjunto de lembranças construídas na sociedade, para além do indivíduo, 


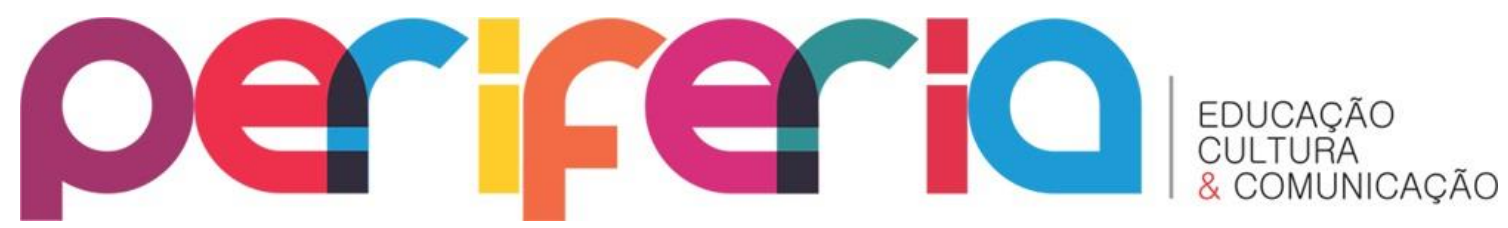

ISSN:1984-9540

DOI: $10.12957 /$ periferia.2020.55035

sendo determinada pela aderência de um grupo a um determinado espaço compartilhado pela coletividade. Assim,

diríamos que cada memória individual é um ponto de vista sobre a memória coletiva, que este ponto de vista muda segundo o lugar que ali ocupo e que esse mesmo lugar muda segundo as relações que mantenho com outros ambientes. (HALBWACHS, 2006, p. 69)

A preservação visa a continuidade das manifestações culturais e a garantia de manter uma identidade cultural. Todo legado histórico que se traduz como bem cultural, deve ser preservado, para que se garanta a transmissão das suas informações às gerações futuras, e para que as mesmas possam vir a ter conhecimento de suas referências passadas.

A principal razão para preservar o patrimônio histórico e cultural é a melhoria da qualidade de vida da comunidade, que implica em seu bem estar material e espiritual. Dessa forma, preservar o acervo documental, recuperar a memória cultural, divulgar a história da região - são esses atualmente, os objetivos do Instituto Histórico da Câmara Municipal de Duque de Caxias. E, compreender uma educação patrimonial para além do patrimônio em si mesmo, na crença de que cultura e fruição dos bens culturais e patrimoniais são questões de cidadania, é o meio de contribuir para a (re)construção das memórias, histórias e identidades de nosso lugar, para que estas se perpetuem e para que outras gerações possam ter acesso a elas.

\section{REFERÊNCIAS}

ALMEIDA, Tania Maria da Silva Amaro de. Olhares sobre uma Cidade Refletida: memória e representações de Santos Lemos sobre Duque de Caxias (19501980). Duque de Caxias: ASAMIH, 2014.

ALVARENGA NETO, Waldemar. O Princípio da Goméia. Revista Pilares da História. Duque de Caxias, ano 8, número 9, pp. 55-62, maio/2009.

ARAÚJO, Marcos Paulo Mendes. O Atual Cenário da Preservação da Memória na Cidade de Nova Iguaçu: uma preocupação com as gerações futuras. Revista Eventos Pedagógicos. v.2, n.3, Número Especial, p. 92 - 100, Ago./Dez. 2011. 


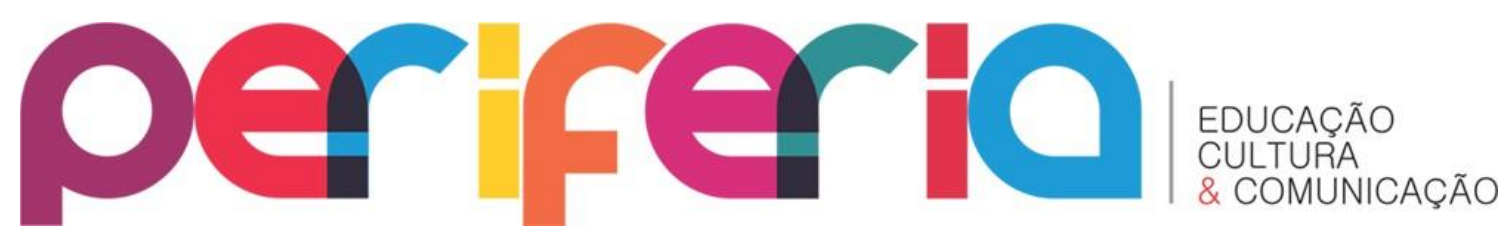

ISSN:1984-9540

DOI: $10.12957 /$ periferia.2020.55035

Disponível

em

http://sinop.unemat.br/projetos/revista/index.php/eventos/article/view/38 1 . Acesso em 09 de agosto de 2020.

BRAZ, Antonio Augusto; ALMEIDA, Tania Maria Amaro de. De Merity a Duque de Caxias: encontro com a história da cidade. Duque de Caxias: APPH-Clio, 2010.

CALLARI, Claudia Regina. Os Institutos Históricos: do Patronato de D. Pedro II à construção do Tiradentes. Revista Brasileira de História, vol. 21 n 40 . São Paulo, 2001. Disponível em: http://www.scielo.br .Acesso em 09 de setembro de 2020.

CARDINI, Franco. A Memória Coletiva no Pensamento de M. Halbwachs. Conferência proferida no Instituto de Psicologia da Universidade de São Paulo, São Paulo: 10 de novembro de 1993. Disponível em http://www.scielo.br/scielo.php?script=sci_arttext\&pid=S0103-

65642006000300004 . Acesso em 21 de setembro de 2020.

CHAGAS, Mário. Museus e Movimentos Sociais. In: Curso de Extensão Educação e Patrimônio Cultural, 14-26 mai. 2007. Niterói: UFF, 2007.

GAMA, Elizabeth Castelano. Um Rei Negro na Baixada Fluminense: memória e esquecimento. Periferia, Universidade do Estado do Rio de Janeiro, vol. 6, núm. 2, , pp. 101-119, julho-dezembro, 2014 Disponível em: https://www.epublicacoes.uerj.br/index.php/periferia/article/view/17274. Acesso em 19 de agosto de 2020.

HALBWACHS, M. A Memória Coletiva. São Paulo: Centauro, 1990/2006.

LACERDA, Stélio. Uma Passagem pela Caxias dos Anos 60. Duque de Caxias: Edição do Autor, 2001.

PESAVENTO, Sandra Jatahy. Cidade, Espaço e Tempo: Reflexões sobre a Memória e o Patrimônio Urbano. In: Cadernos do LEPAARQ - Textos de Antropologia, Arqueologia e Patrimônio, v.2, n.4, p. 9-17, jul./dez., 2005. Disponível em https://periodicos.ufpel.edu.br/ojs2/index.php/lepaarq/article/view/893 . Acesso em 21 de agosto de 2020.

_ História, Memória e Centralidade Urbana. In: Revista Mosaico, v.1, n.1, p.3-12, jan./jun., 2008. Disponível em http://seer.ucg.br/index.php/mosaico/article/view/225/179. Acesso em 12 de setembro de 2020.

MENDES, Andrea. Candomblé Angola e o Culto a Caboclo: de como João da Pedra Preta se tornou o Rei Nagô. Periferia, Universidade do Estado do Rio de

Periferia, v. 12, n. 3, p. 129-153, set./dez. 2020 


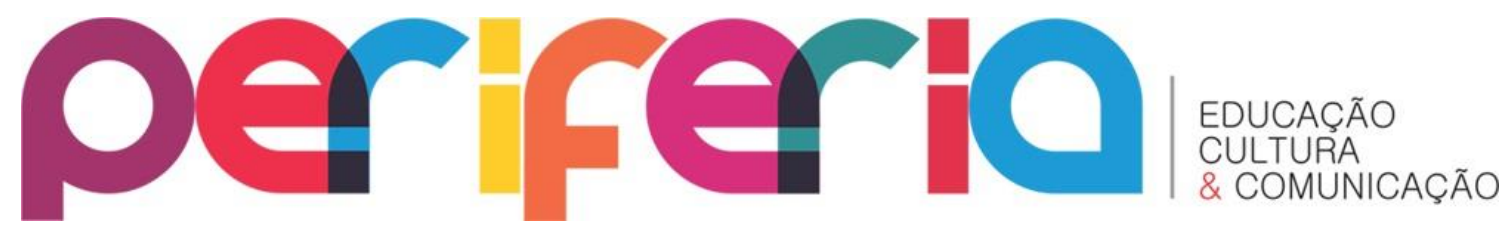

Janeiro, vol. 6, núm. 2, pp. 120-138, julho-dezembro/2014. Disponível em: https://www.e-

publicacoes.uerj.br/index.php/periferia/article/view/17276/12712. Acesso em 19 de agosto de 2020.

NAJJAR, Jorge e Rosana. Reflexões sobre a relação entre educação e arqueologia: uma análise do papel do Iphan como educador coletivo. In: FILHO, M. F. L.; BEZERRA, M. Os Caminhos do Patrimônio no Brasil. Goiânia: Alternativa, 2006. pp. 171-182.

NASCIMENTO, Andrea. De São Caetano à Caxias: um estudo de Caso sobre a trajetória do Rei do Candomblé Joãosinho da Goméa. 105 folhas. Monografia. Licenciatura Plena em História. Universidade Estadual do Rio de Janeiro, Rio de Janeiro, 2003.

NORA, Pierre. Entre Memória e História. A Problemática dos Lugares. Projeto História. São Paulo, n. 10, dez, 1993. Disponível em http://revistas.pucsp.br/index.php/revph/article/viewFile/12101/8763 . Acesso em 09 de setembro de 2020.

SANTOS, Adriana Batalha dos Santos. Tudo Aqui Tem Axé: a presença do desativado terreiro da Goméia em Duque de Caxias. In: $31^{\mathrm{a}}$ REUNIÃO BRASILEIRA DE ANTROPOLOGIA, 2018, Brasília. 31 ${ }^{a}$ Reunião Brasileira de Antropologia. Brasília: ABA, 2018. Disponível em https://docplayer.com.br/108318532-Tudo-aqui-tem-axe-a-presenca-dodesativado-terreiro-da-gomeia-em-duque-de-caxias-1-autor-adriana-batalhados-santos.html. Acesso em 09 de setembro de 2020.

NORONHA, Taís. Joãozinho da Goméia: memórias do Babalorixá em Duque de Caxias (1914-1971). 127 folhas. Dissertação. Mestrado em Humanidades, Culturas e Artes, UNIGRANRIO, Duque de Caxias, 2017.

SOUZA, Marlucia Santos de. Escavando o Passado da Cidade. Duque de Caxias: APPH-Clio, 2014.

TORRES, Rogério. Caxias de Antigamente. Rio de Janeiro: Letras e Versos, 2015. 